\title{
Press coverage of the German reunification issue in a long-term perspective, 1990-2014
}

\author{
Melanie Leidecker-Sandmann \\ ORCID: 0000-0001-7203-2448 \\ KARLSRUHE INSTITUTE OF TECHNOLOGY, GERMANY \\ Jürgen Maier \\ ORCID: 0000-0001-8301-5125 \\ UNIVERSITY OF KOBLENZ-LANDAU, GERMANY \\ Michaela Maier \\ ORCID: 0000-0002-7505-691X \\ UNIVERSITY OF KOBLENZ-LANDAU, GERMANY
}

DOI: 10.19195/1899-5101.12.1(22).1

\begin{abstract}
This paper analyses the long-term coverage (1990-2014) of German reunification by six German newspapers. Our quantitative content analysis shows how often the press covers the event, what the content of the coverage is, and how journalists evaluate the reunification process. As we have analysed newspapers of different locations, ranges, types, and editorial lines, we can see whether newspapers cover German reunification differently. Our analysis shows that the amount of coverage of reunification quickly decreases, and only a few articles are published prominently. The press reports on more differences between East and West Germany than similarities; about one third of the articles mentions problems and conflicts, although they become less important over time. All in all, positive evaluations of German reunification outweigh negative judgments and increase over time. We see evidence that the placement, content, and tone of coverage highly depends on the type, editorial line, range, and location of the newspapers.
\end{abstract}

KEYWORDS: German reunification, turnaround, press coverage, quantitative content analysis, time series.

\section{INTRODUCTION}

About 25 years ago, one of the most spectacular events in recent German history took place: on 3 October 1990, the partition of Germany into East and West officially 
ended. Although millions of Germans were witnesses to Mikhail Gorbatchev's Glasnost and Perestrojka policy, the peaceful demonstrations in the German Democratic Republic (GDR), the fall of the Berlin Wall, the collapse of the communist regime in Eastern Germany, and finally - and most importantly - the administrative reunification of both parts of the country, only a few people were personally exposed to these events or had contact to leading figures who were involved in these processes. This is particularly true for most West German residents. For instance, while hundreds of thousands of people were on the spot when the Berlin Wall fell on 9 November 1989, millions of people were not. In sharp contrast to those who cheered the first people crossing the inner-German border, the vast majority was only able to follow this event through the media.

The media played an important role for German reunification, as this process was very complex and often turbulent. Therefore, it was quite difficult for citizens to keep track of what was going on. In this phase, the mass media provided important information to the public. But the media did not only play an important role in the past. It still has a significant impact by shaping the pictures in our heads about German reunification as a historic event (Früh et al., 2011). As temporal distance to the years of 1989/1990 increases, the media more and more determine what pieces of information are stored in our collective memory (Löser, 2013). In addition, for those too young to personally remember the occurrences during this time, the media play a major role in forming individual assessments of German reunification. In other words: the media probably affect what we think about when it comes to German reunification, they influence what pieces of information we use when we need to evaluate certain outcomes of or authorities involved in the reunification process, and they offer specific perspectives when we consider issues related to German reunification.

Although the consequences of the media's coverage of German reunification for the public's political knowledge, attitudes, and behaviour are not the subject of this paper, their potential impact still points to some important questions: What kind of information do the media provide to the public? How has the coverage changed over time? Are there differences between media outlets in covering German reunification?

Based on a content analysis of six German newspapers over the course of 25 years, we investigate the amount, the content, and the tone of the press coverage of the German reunification issue. Our data indicate that the coverage of this issue has dramatically declined over time. Although the evaluation of German reunification is in general positive, reports on East-West differences outweigh articles that emphasise similarities. Furthermore, problems and conflicts are an important topic. As we find differences in the coverage of German reunification between the newspapers, we also try to explain which factors affect the press' view on this issue. Our finding is that the location, the range, the type, and the editorial line of a newspaper have a significant impact on the presentation and evaluation of this issue. 
Our study contributes to the state of research in several aspects. It adds new quantitative findings to an underexplored research topic in the sense that it illustrates how (1) the structure and (2) the tone of press coverage of the German reunification issue have changed over time, it shows (3) differences between newspaper types, and it analyses (4) important factors that might influence the style of coverage in a multivariate manner (which is scarcely done in media content analyses).

\section{MEDIA COVERAGE OF THE GERMAN REUNIFICATION ISSUE: PREVIOUS RESEARCH}

A large body of research indicates that the media's coverage of politics is able to influence individual perceptions about politics, political attitudes, and political behaviour - for example, agenda setting research, priming and framing (e.g., Maurer, 2010; Scheufele \& Tewskbury, 2007). Moreover, citizens often take media coverage as an indicator of public opinion. Hence, the mass media serve as a yardstick in order to find out which opinions are more popular than others (Noelle-Neumann, 1983). Applying these arguments to the special case of German reunification, it can be expected that the mass media shape individual perceptions of and attitudes towards this event.

Interestingly enough, the question of how the media have covered German reunification has been the subject of only a very few empirical studies. ${ }^{1}$ The available research often consists of case studies based on a limited media set, a limited time frame, or a limited number of variables. Because the studies are quite heterogeneous, it is very difficult to compare their results and make statements about trends in media coverage. In total, only three studies are based on quantitative content analyses. ${ }^{2}$ First, the study of Löser (2013) includes 25 newspapers covering the twentieth anniversary of German reunification. His findings are based on a quantitative content analysis of almost 14,000 articles. He concludes that in 2009 German reunification is an 'unobtrusive issue' (Löser, 2013, p. 187) for West German newspapers. They highlight this event only on and around the anniversary itself. In contrast to this, East German newspapers report more often on the reunification process. In addition, they frequently connect their coverage to the incidents of the years 1989 and 1990. The tenor of the coverage is usually neutral. If press reports contain evaluations, positive coverage outweighs negative coverage. Secondly, in 2010 the media research institute Media Tenor published a content analysis of three major German TV stations on the evaluation of German re-

${ }^{1}$ In contrast to this, many more studies have focused on how the media report about East Germany and the East Germans (e.g., Ahbe, 2009; Kolmer, 2009; Früh et al., 1999; Kollmorgen \& Hans, 2011).

${ }^{2}$ In addition, some studies follow a qualitative approach (e.g., Korngiebel \& Link, 1992; Rother, 1992). 
unification since 1996 (Media Tenor, 2016a). In line with Löser (2013), they show that coverage only takes place around the date of the anniversary. In addition, the number of reports has declined over time. Their results indicate that German reunification in general has been positively evaluated. Nevertheless, specific issues related to German reunification, for example, social issues, demographic developments, or the equalisation of living conditions, are usually perceived as problems and therefore received negative evaluations. Thirdly, in two more recent Media Tenor studies, TV and press coverage between 2001 and 2014 (Media Tenor, 2016b) respectively 2001 and 2016 (Media Tenor, 2016c) is analysed. The main results are that German reunification as well as the living conditions in East Germany do not seem to matter much to German media anymore - at least with the exception of jubilees. When the media do cover German reunification, they publish five times more negative reports than positive articles (Media Tenor, 2016b). In 2016, also political actors connected with German reunification were evaluated more critically compared to the previous year (Media Tenor, 2016c).

\section{HYPOTHESES ABOUT MEDIA COVERAGE OF GERMAN REUNIFICATION}

We argue that two factors will have a major impact on press coverage concerning the German reunification issue: time and newspaper characteristics (i.e., the location, range, type, and the editorial line of the newspaper). These factors can have consequences for the amount of articles published, for the placement and the content as well as for the tone of an article. Based on previous research and on more general findings on media coverage of politics, we formulate several hypotheses and research questions connecting the factors potentially affecting press coverage and their possible consequences (for an overview see Table 1).

Table 1. Overview of the formulated hypotheses and research questions

\begin{tabular}{|l|c|c|c|}
\hline $\begin{array}{c}\text { Factors potentially } \\
\text { affecting the coverage } \\
\text { of the German } \\
\text { reunification issue }\end{array}$ & Amount of coverage & $\begin{array}{c}\text { Placement and content } \\
\text { of coverage }\end{array}$ & $\begin{array}{c}\text { Tone } \\
\text { of coverage }\end{array}$ \\
\hline Time & H1, H2 & H3 & H4 \\
\hline $\begin{array}{l}\text { Location of newspa- } \\
\text { per }\end{array}$ & H5, H6 & H10 \\
\hline Range of newspaper & H7, H8, H9 & H12 \\
\hline Type of newspaper & H11 & H16 \\
\hline $\begin{array}{l}\text { Editorial line of news- } \\
\text { paper }\end{array}$ & H13, H14, H15 & \\
\hline
\end{tabular}

Source: Authors. 


\section{Time}

According to the Media Tenor (2016a, b, c) studies, media coverage of German reunification has declined over time. Hence, we expect that the number of articles published by the newspapers under our investigation has also declined (H1). In addition, available research indicates that German reunification is an 'unobtrusive issue' (Löser, 2013, p. 187). Nevertheless, there is also evidence that the media pay special attention to this issue on the anniversaries of this event (Löser, 2013). For symbolic reasons, the fifth, tenth, fifteenth, and twentieth anniversaries are more important than the other years. Hence, we expect that media coverage at significant anniversaries exceeds the coverage at 'normal' anniversaries (H2).

After the parliaments in both parts of the country decided that the GDR would join the Federal Republic of Germany (FRG), politics and administration were confronted with a vast number of problems that had to be solved to reunite Germany. Today, most of these problems have been solved (Gabriel et al., 2015). As the media tend to focus more on negative than on positive information, ${ }^{3}$ the basis for negative coverage of the German reunification process has considerably declined over time. Therefore, we assume that the share of articles focusing on problems and conflicts has decreased (H3) and that the evaluation of German reunification has become more favourable over time $(\mathrm{H} 4)$.

\section{Newspaper characteristics: Location}

Available research has demonstrated that different newspapers cover German reunification differently. In particular, Löser (2013) has demonstrated that there are differences between East and West German newspapers. ${ }^{4}$ The reasons for these differences are, on the one hand, that the East German population was more personally affected by the changes evoked by the reunification process than citizens from West Germany. On the other hand, problems of the reunification process were often most visible at the local level that had to cope with the implementation of standards enacted at the state or the federal level. Of course, most of these implementations concerned East Germany. Hence, the reunification issue should have higher relevance for East German newspapers.

Accordingly, we expect differences in news coverage, which can be traced back to the location of a newspaper. First, we assume that our analysed East German newspaper places stories on German reunification more prominently (H5). Second, we expect that the East German newspaper particularly emphasises an East German perspective on German reunification, whereas West German newspapers tend

\footnotetext{
${ }^{3}$ Negativity is seen as an important news factor, which makes an event more newsworthy (e.g., Kepplinger \& Weißbecker, 1991; Leidecker, 2015).

${ }^{4}$ East German regional newspapers cover it more often, place it more prominently and cover it more extensively. Further, they especially emphasise regional (East German) aspects or events of the German reunification, while West German newspapers cover the German turnaround more often from a nationwide perspective (Löser, 2013).
} 
to cover this event more often from a nationwide perspective (H6). In addition, we are interested if the location of a newspaper affects the evaluation of this event (RQ1). Unfortunately, the available research provides no clear empirical evidence to formulate a hypothesis.

\section{Newspaper characteristics: Range}

Löser (2013) has also shown that regional and national newspapers differ in their coverage of German reunification. Based on the arguments outlined above - that is, the higher visibility of consequences associated with the implementation of standards at the local level - the reunification issue should be of higher relevance for regional newspapers. Therefore, we expect more stories about German reunification on the front page of regional newspapers than on the front page of national newspapers (H7). Furthermore, national newspapers should focus more often on the 'big picture' and the overarching consequences of German reunification. In contrast to this, regional newspapers should use more narrow frames on this issue (H8). In addition, regional newspapers should report more about problems and conflicts associated with the reunification process than is the case for national newspapers (H9). As a consequence, we also assume that regional newspapers evaluate German reunification more negatively than national newspapers (H10).

Newspaper characteristics: Type

A large body of research has found differences in the coverage of politics between quality and tabloid media (Schulz, 2011; Leidecker, 2015). For instance, there are studies which have found that the focus on conflicts is more important for tabloid newspapers (Brichta, 2006; Schulz, 1976). Hence, we expect differences caused by the type of newspapers and assume that tabloids link their coverage more often to problems or conflicts related to the reunification process than quality newspapers (H11). We also expect that tabloid newspapers evaluate German reunification more negatively than quality newspapers (H12).

\section{Newspaper characteristics: Editorial line}

Research has demonstrated that the presentation of politics also depends on the editorial line of the media. As German reunification was put into action by a conservative government, we expect on the one hand that conservative newspapers try to attract attention to this topic and to positively evaluate this historical event to praise particular parties and politicians. On the other hand, leftist newspapers should tend to downplay the importance of the event by only reporting on German reunification if the situation calls for it. In addition, they should tend to be more critical about the conception of the reunification process and its achievements. Hence, we assume that stories about German reunification can be found more often on the front pages of conservative newspapers than on the title page of 
leftist newspapers (H13). In addition, we expect that conservative newspapers focus more on similarities (H14) and less on problems or conflicts than leftist newspapers (H15). Finally, we expect that conservative newspapers evaluate German reunification more positively than leftist newspapers (H16).

\section{DESIGN AND METHOD}

\section{Sample}

Our analysis is based on a quantitative content analysis of six German newspapers over the course of 25 years. ${ }^{5}$ We chose newspapers (instead of TV news, for example) for practical and substantial reasons. German newspaper editions are much better and more systematically preserved and accessible in several press archives and libraries compared to radio or TV news. Additionally, communication research shows that the daily press - compared to TV - is a medium that is widely used for political information, while TV predominantly supplies the recipients' need for entertainment (Schulz, 2001). Further, the amount of political coverage is more extensive in newspapers and supplies readers with more background information than TV coverage (Schulz, 2011).

There is a lot of evidence that different media outlets cover politics differently. There are indications, too, that this is also the case with respect to German reunification (Löser, 2013). In order to make intra-medial comparisons, we analyse the coverage of six German newspapers: Berliner Zeitung, BILD, Frankfurter Allgemeine Zeitung, Süddeutsche Zeitung, Der Tagesspiegel, Die Tageszeitung. We chose these newspapers in order to systematically vary the location (East vs. West), the range (regional vs. national), the type (quality vs. tabloid), and the editorial line (liberal to conservative) (Maurer \& Reinemann, 2006; Berliner Zeitung, 2014; Berliner Verlag, 2014; see Table 2). Of course, our newspaper selection represents only a very small section of the newspaper landscape in Germany. The focus of our study is on highcirculation, national daily newspapers, because they have a significant influence on the media system and on the reporting of other media (so-called newspapers of record) (Maurer \& Reinemann, 2006). Their coverage may, in a way, be considered 'representative' of the coverage in (regional) German newspapers. The Frankfurter Allgemeine Zeitung and the Süddeutsche Zeitung are two such newspapers of record. In addition, Die Tageszeitung — despite its lower circulation - also appeared analytically interesting, as it covers 'post-materialist' issues that are of importance to society as a whole, and as it is strongly perceived by journalists. BILD was selected as the only national tabloid newspaper in Germany. It has been for decades the most successful newspaper in Germany with the highest circulation (Brichta,

${ }^{5}$ Data collection was supported by a grant of the Commissioner of the Federal Government for the New Länder. The data presented here is part of a larger content analysis of German newspapers. For more information, see: Gabriel et al., 2015. 
2006). In order to include German regional newspapers in our analysis, the Berliner Zeitung and Der Tagesspiegel were selected as two of the highest-circulation regional newspapers in Berlin. Their coverage seems well-suited for a comparison, because it relies on the same local problems and events. Der Tagesspiegel is read mainly in the western districts of the German capital. By contrast, the Berliner Zeitung only appeared in East Berlin until 1990 and since then has been read mainly in the eastern districts of the capital (Berliner Zeitung, 2014; Berliner Verlag, 2014).

Table 2. Characteristics of the newspapers represented in the sample

\begin{tabular}{|l|c|c|c|c|}
\hline & Location & Range & Type & Editorial line \\
\hline Berliner Zeitung & East & Regional & Quality & Left \\
\hline BILD & West & National & Tabloid & Conservative \\
\hline Frankfurter Allgemeine Zeitung & West & National & Quality & Conservative \\
\hline Süddeutsche Zeitung & West & National & Quality & Left-liberal \\
\hline Der Tagesspiegel & West & Regional & Quality & Liberal-conservative \\
\hline Die Tageszeitung & West & National & Quality & Left \\
\hline
\end{tabular}

Source: Authors.

Our content analysis covers the years 1990 to 2014. For each year of this time period, we analyse the press coverage of the German reunification process shortly before and after the jubilee of German reunification on 3 October. Strictly speaking, our analysis covers the period from 1 October until 4 October for every year from 1990 to 2014 (the jubilee itself is a public holiday; no newspapers are published on this day). ${ }^{6}$ We chose these days according to previous research in this field, which indicates that the vast majority of the media coverage takes place around the anniversary (Löser, 2013; Media Tenor, 2016a; Gabriel et al., 2015).

For all six newspapers, every relevant article on the front page, in the political section, the commentary, and feature sections of the newspapers was included. In the case of the two regional newspapers, the local or regional section was analysed, too. Other sections (economy, culture) were left out, although they also may have included articles connected to German reunification. To ascertain the relevant articles, we first identified all articles referring to German reunification, respectively the turnaround (or synonyms) in the headline, caption, subheading, trailer, or

${ }^{6}$ In addition, we only analyse Monday to Saturday editions as most of the selected newspapers do not provide a Sunday edition. 
first paragraph of the article. In a second step, we examined if German reunification, respectively German turnaround is the main topic of the article. Articles that only mentioned German reunification (or turnaround) without making it the main part of the story were eliminated. In total, we identified $N=766$ articles (Berliner Zeitung: $N=185$, BILD: $N=77$, Frankfurter Allgemeine Zeitung: $N=120$, Süddeutsche Zeitung: $N=71$, Der Tagesspiegel: $N=231$, Die Tageszeitung: $N=82$ ).

\section{Coding}

In order to test our hypotheses and research questions we coded the placement, the content, and the tone for each article. In particular, to capture the placement and the content we used the following variables:

- Prominence of coverage: The placing of an article serves as an indicator of the relevance or importance journalists ascribe to the issue. The more prominently an article is placed in the newspaper (e.g., as a lead story on the title page), the more important the issue is considered by the journalist (Schulz, 1976).

- Frame of coverage: Frames are considered as 'modes of presentation that journalists and other communicators use to present information [...] to reduce the complexity of an issue' (Scheufele \& Tewskbury, 2007, p. 12). In this paper, we examined if the reunification issue is discussed from a specific perspective. On the one hand, we distinguish regional frames, that is, a 'pure' East or a West German perspective. This angle is present if an article exclusively refers to either East Germans or West Germans and, for example, describes the consequences of German reunification only for the East (West) Germans. On the other hand, we also recorded the use of other frames. In particular, we coded whether an article takes an all-German perspective (i.e., the article does not differentiate between East and West Germans or at least covers both perspectives more or less equally), a European perspective (the main topic is described from the point of view of at least one European country other than Germany), or an international perspective (the main topic is described from the point of view of a country outside Europe).

- Mentioning of differences: A key part of the German reunification process is the integration of East and West Germany. Two previously separated parts have to grow together, in a societal, economic, and also in a mental sense. This is one of the major challenges of German reunification: to break down the so-called 'wall in the heads' of Germans. To assess this perspective we coded whether differences between East and West Germany, respectively East and West Germans, are a topic of coverage.

- Mentioning of similarities: Analogous to the mentioning of differences, we checked how often similarities between East and West Germany, respectively East and West Germans, are mentioned in the newspaper articles.

- Mentioning of problems: We further coded if the article describes the (process of) German reunification as a topic fraught with problems. This is the case if 
negative aspects of the German reunification (process) are explicitly mentioned or if positive aspects are denied.

- Mentioning of conflicts: A conflict was coded if an article describes situations in which different interests, goals, or ideals concerning the reunification (process) interfere (e.g., differences of opinion are explicitly mentioned).

In addition, for each article we coded three different variables capturing evaluations of German reunification:

- evaluations of the (idea of) German reunification in general

- evaluations of the reunification record

- evaluations of the expected development of the integration process.

We differentiated between these three aspects of German reunification evaluations following the style of a Media Tenor (2016a) analysis to be able to make sophisticated interpretations. As far as our definition is concerned, an article includes an evaluation if it attributes implicitly or explicitly positive or negative characteristics to German reunification. Evaluations were coded on the basis of the whole article (not on the statement level) - the overall impression of the articles was decisive.

In order to ensure a high quality of data, all coders participated in thorough training. Reliability tests were run for each category. For formal variables, reliability coefficients vary between .92 and 1.00 (Holsti's $R$; for dichotomous variables), respectively .92 and 1.00 (Krippendorff's alpha; for variables with three or more categories). For content variables, the coefficients range between .70 and .95 (Holsti’s $R$ ).

\section{Analysis}

In order to analyse our data we aggregate the values for each variable and each newspaper by year. Hence, we end up with a time series for each newspaper including one measure (percentage, mean) for each year $(N=25)$. Based on these values we are able to compare the coverage between newspapers without having to consider the number of published articles. In addition, we are able to test for trends over time. In order to analyse the impact of newspaper characteristics on the placement, the content, and the tone of press coverage, we create a stacked data set including 25 measurement points for each newspaper. Hence, the total number of cases for these analyses is 150 .

In addition, we take into account the fact that especially the observations of the tenor of the coverage lack independence: it is highly unlikely that newspapers develop fundamentally different positions to German reunification from year to year. For control for these dependencies we estimate the impact of newspaper characteristics on our dependent variables using OLS regression with robust clustered standard errors. 


\section{RESULTS}

\section{Development of coverage}

Although the question of how to implement German reunification kept parties, politicians, and administrations at all levels of the political system busy for many years, the press very quickly lost interest in covering this issue (see Figure 1). For instance, whereas the newspapers included in our sample published 134 articles in 1990, this number dropped to 55 articles in 1991 and 20 articles in 1992. In most of the subsequent years, coverage varied around 30 articles per year. The estimated average decline of coverage between 1990 and 2014 is $1.736($ S.E. $=.675)$ articles per year. This decrease is statistically significant $(p<.05 ; N=25)$. Although this trend can be observed for all newspapers, it reaches significance only in four out of six cases. By and large, $\mathrm{H} 1$ can be confirmed.

In addition, Figure 1 gives the impression that at some special jubilees (i.e., the fifth, tenth, fifteenth, and twentieth anniversary) the press tends to cover German reunification more intensively than in off-years. A more formal test shows that the average number of articles at special jubilees is 47.8 , whereas in other years this number is only 27.4. Nevertheless, this difference is statistically not significant $(p>.05 ; N=25)$. The general tendency to focus more on the German reunification issue at jubilees also holds for single newspapers. Still, the difference is significant only for one newspaper. In general, $\mathrm{H} 2$ has to be rejected.

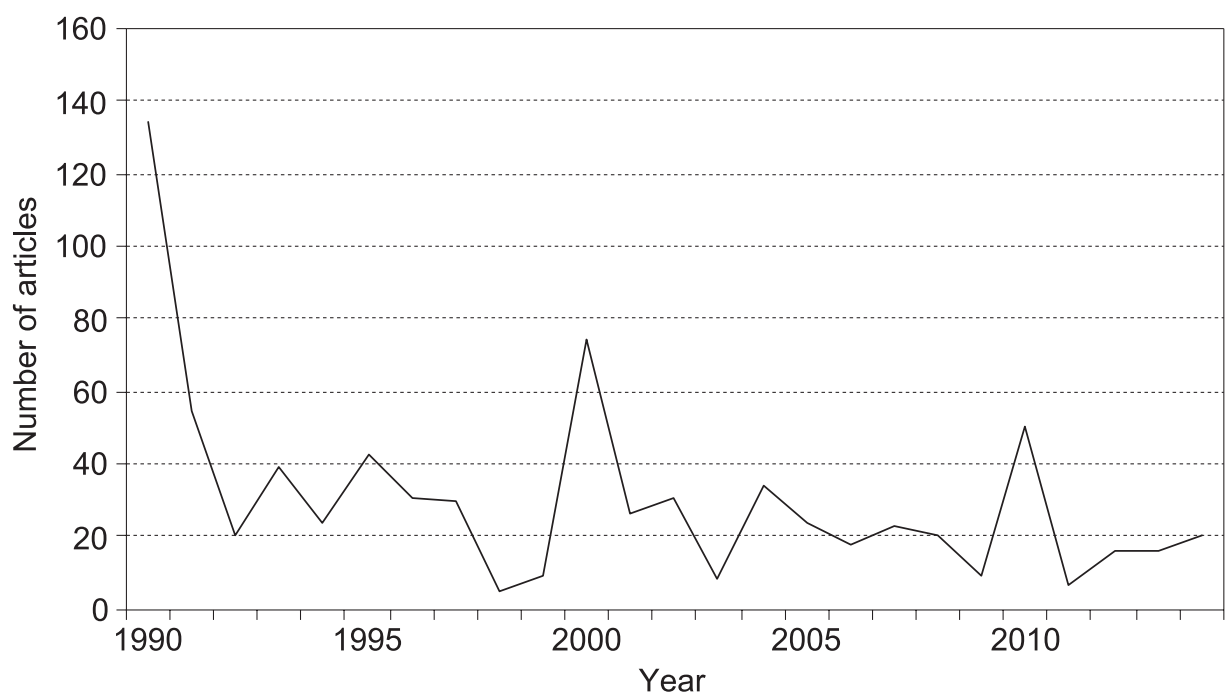

Figure 1. Development of press coverage, 1990-2014 (in absolute numbers)

Source: Authors. 


\section{Placement and content of coverage}

The analysed newspapers covered German reunification relatively prominently. Almost every fifth article (18.3\%) published on the German reunification issue appeared on the front page (Table 3). Most of the reports on this topic used an 'all-German' perspective. In contrast to this, only about one tenth $(11.0 \%)$ of the coverage specifically employed an East or a West German perspective. Thus, there does not seem to be a 'wall in the heads' (an explicit differentiation between East and West Germany in peoples' minds) of journalists. However, three out of ten articles (30.8\%) focus on differences between East and West Germany, whereas only one tenth $(10.6 \%)$ of the coverage highlights similarities between both parts of the country. In addition, more than a quarter $(26.6 \%)$ of the coverage is dedicated to problems (almost all of those articles point to deficits, whereas only very few articles report on solved problems); $6.1 \%$ of the articles mention conflicts. Thus, the German reunification process does not seem to be finished as yet.

The structure of press coverage has changed over time. Articles tend to be published less prominently today than in the past and focus less on differences and problems. In contrast to this, particular East or West German frames have become more popular, similarities - but also conflicts - are reported more often. Except for the decrease in reports on problems, none of the described trends is statistically significant.

If we compare the focus of coverage across categories of newspapers, it turns out that differences only rarely occur. Firstly, conservative newspapers report more prominently on German unification than left-wing newspapers. As the placing of an article may be regarded as a key indicator of the importance journalists ascribe to the issue, we interpret that the German reunification issue seems to be more relevant for conservative compared to leftist newspapers.

Secondly, regional frames are more often employed by the newspaper located in East Germany and by regional newspapers. This finding perhaps suggests that the 'wall in the heads' is more existent for readers of regional newspapers than for readers of national newspapers. In contrast, newspapers based in West Germany and newspapers with a national range more often use an all-German perspective.

Thirdly, conservative newspapers report more often about similarities between both parts of the country than left-wing newspapers. As German reunification occurred during a conservative government (consisting of the CDU, CSU, and FDP under the leadership of chancellor Helmut Kohl), conservative newspapers understandably emphasise a successful integration of East and West Germany.

As newspapers are assigned to multiple categories, the presented results suffer from a lack of control of potential variables influencing press coverage. In addition, time and particular events like a special jubilee can have an impact on the coverage of the reunification issue. Therefore, we set up multivariate models to simultaneously estimate the impact of our independent variables on the placement and the content of press coverage. 


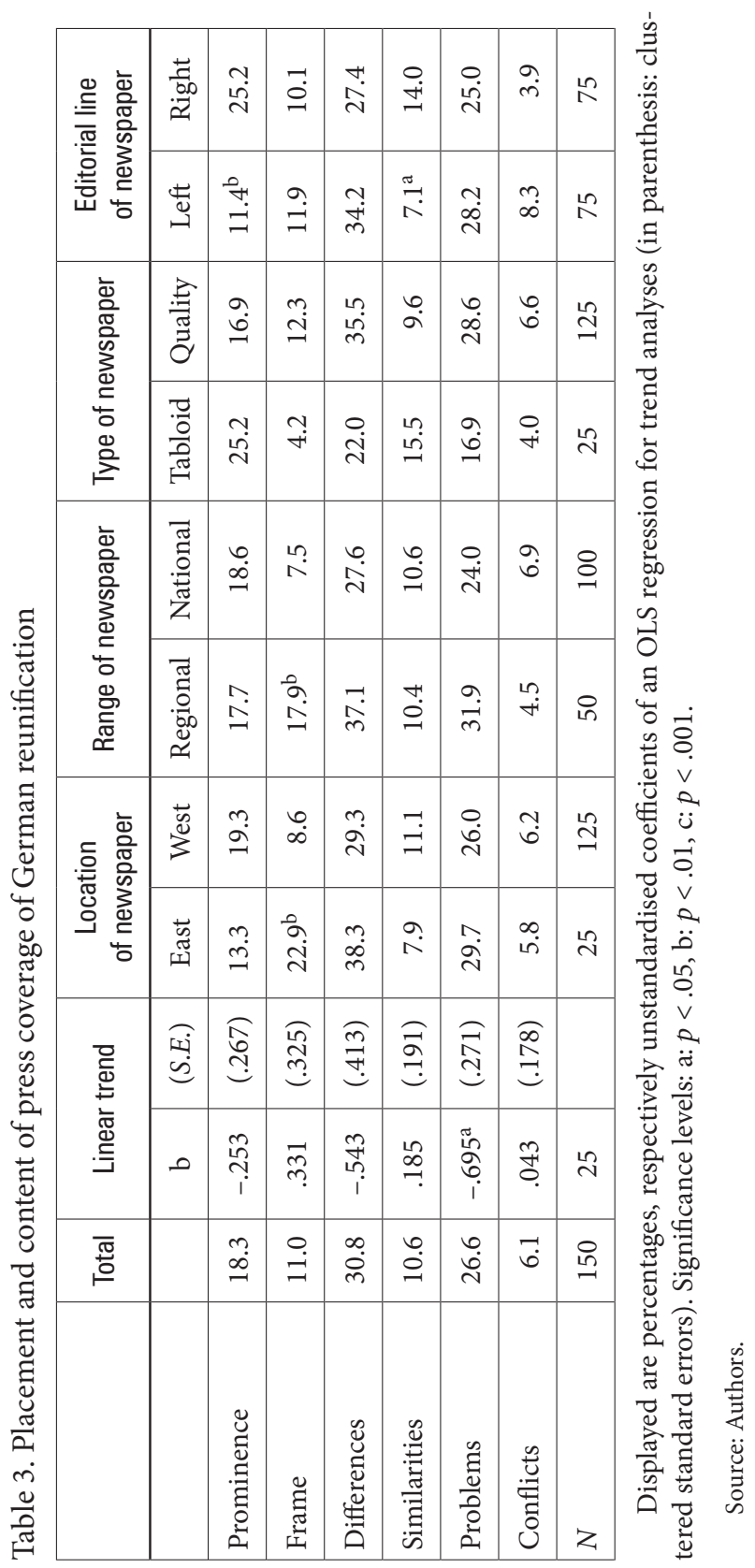


Our results indicate that all characteristics of newspapers specified in this paper have an influence on the coverage of the German reunification issue (Table 4).

Firstly, the location of a newspaper influences the press coverage. Compared to West German newspapers, articles on the reunification issue in our analysed East German newspaper are much more obvious as they appear more frequently on the front page. Hence, $\mathrm{H} 5$ is confirmed. In addition, the East German newspaper takes a regional frame significantly more often when it discusses German reunification. This result supports H6.

Secondly, the range of a newspaper affects the prominence of the coverage and the focus on East-West differences, problems, and conflicts related to the German unification process. National newspapers cover the reunification issue significantly more prominently than regional newspapers. This finding contradicts H7. In addition, national newspapers mention differences and problems less often but emphasise more conflicts, which is in line with $\mathrm{H} 9$. H8 cannot be confirmed as regional and national newspapers do not differ in their use of specific frames.

Thirdly, the type of newspaper matters. Quality newspapers cover German reunification more prominently, take a regional perspective more often, and focus on differences, problems, and conflicts more frequently (but less often on similarities) than tabloid newspapers. As our hypothesis stated that tabloid newspapers report on negative aspects of the reunification process more often (i.e., problems and conflicts), we have to reject H11. One possible explanation for this unexpected finding might be that especially quality newspapers consider a critical style of coverage to be a sign of quality. This assumption is confirmed by Reumann (2002) who connects a critical or controversial style of coverage with 'hard-news'-coverage. Also, a content analysis by Engesser et al. (2014) showed that in contrast to common expectations tabloid newspapers provide political news with the least negative touch. Additionally, in the context of a content analysis of lead stories in German newspapers, Leidecker (2015) found out that BILD, compared to quality and regional newspapers, contained the least amount of conflict-laden lead stories.

Fourthly, the editorial line of a newspaper influences the coverage of the German reunification issue. Conservative newspapers put their articles significantly more often on the front page, are more likely to take a regional perspective, highlight similarities and downplay conflicts than liberal newspapers. Hence, H13, H14 and H15 can be confirmed.

Furthermore, significant negative trends for the coverage of differences and problems indicate that the focus of press coverage on these aspects of the reunification issue has become less intense over time. The average decline is .7 percentage points (differences) respectively .9 percentage points per year (problems). These findings confirm $\mathrm{H} 3$ - and might suggest that the reunification process, the integration of East and West Germany, is well in progress. In contrast, there is no impact of jubilees after controlling for other factors. 
Melanie Leidecker-Sandmann, Jürgen Maier, Michaela Maier

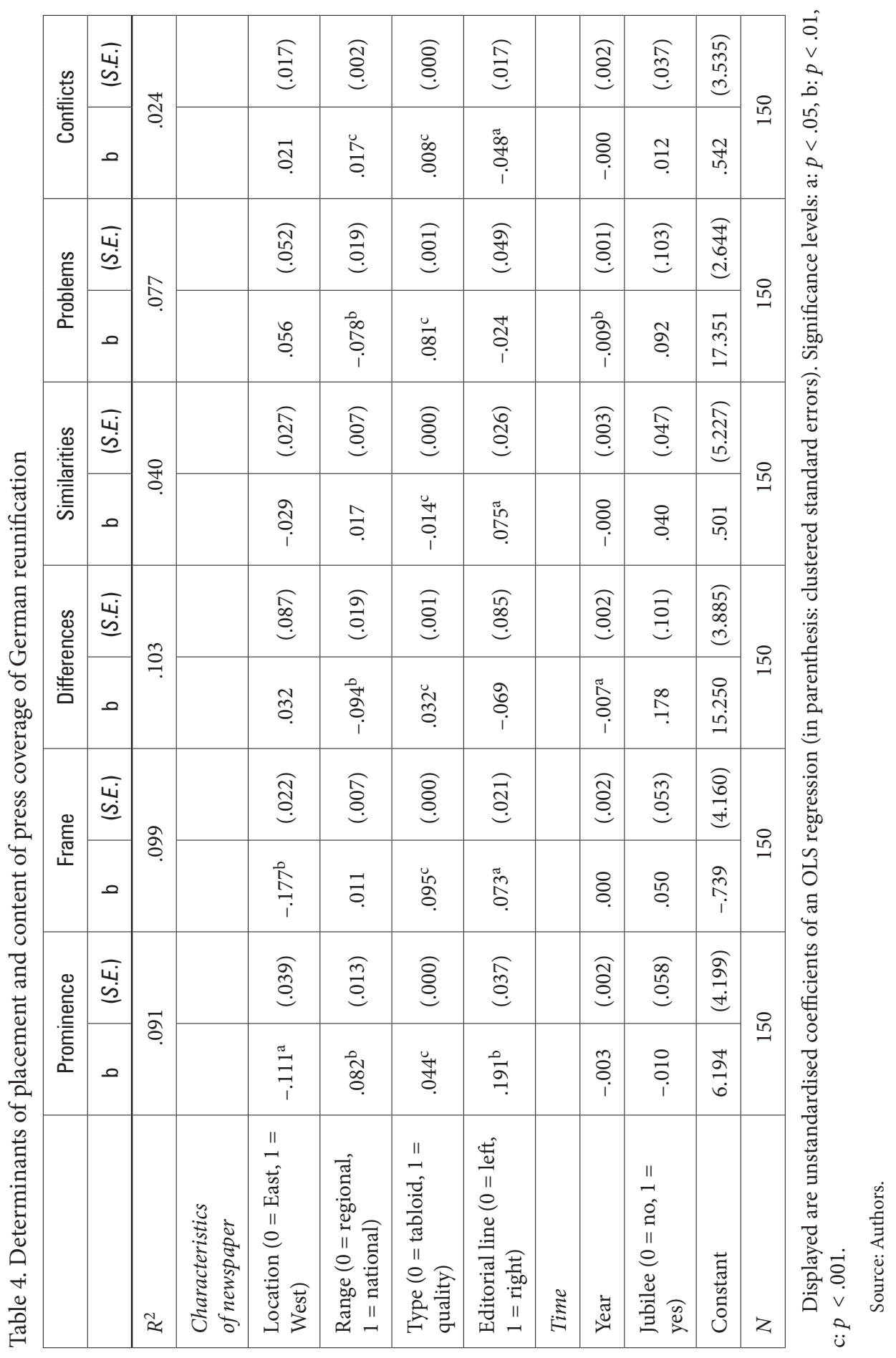




\section{Share of press coverage including evaluations of German reunification}

The analysis of the tone of coverage of German reunification indicates that this topic is often a subject of journalistic evaluation (Table 5). Seven out of ten articles include judgements about the reunification in general. In addition, almost half of the articles $(45.3 \%)$ contain an evaluation of the reunification record. Furthermore, more than one quarter (27.6\%) of the coverage focuses on expectations about the further developments of German reunification. Over the course of a quarter of a century, evaluations of the further developments of German reunification have decreased significantly. The average decline is almost .8 percentage points per year. Furthermore, there are no significant differences for the share of articles including evaluations of German reunification across different categories of newspapers.

Again, our bivariate analyses do not control for potential variables influencing the share of articles the press dedicate to the evaluation of German reunification. The estimation of a multivariate model makes clear that two characteristics of newspapers influence the share of articles that include evaluations of this topic (Table 6). First, the type of newspaper has a significant impact on every indicator analysed. Quality newspapers evaluate reunification in general and the reunification record more often than tabloid newspapers. In contrast to this, they include judgments about future developments less often. Secondly, the editorial line influences how German reunification in general is evaluated. Articles in conservative newspapers include such evaluations significantly less often than reports in liberal newspapers.

Furthermore, there is a significant negative trend concerning the share of articles that evaluate the reunification record and the further developments of the reunification process. However, the size of this effect is not very large. Finally, in jubilee years the press evaluates the reunification record significantly more often than in off-years. Again, the size of the measured difference is not very substantial.

\section{Tone of press coverage}

Our content analysis reveals that, in general, positive evaluations outweigh negative judgements (Table 5). This is especially true for ratings about German reunification in general (on average +.7 scale points on a scale from -1 to +1 ). In addition, the press publishes more positive than negative articles on expectations about the future of German reunification (+.3) and the reunification record (+.1). Judgements on reunification in general and particularly on the reunification record become significantly more positive (on average +.014 respectively +.034 scale points per year). These findings may indicate that the process of integrating East and West Germany is heading in the right direction. Furthermore, there are consistent differences between tabloid and quality as well as between left and right newspapers. The overall pattern is that tabloid and conservative newspapers rate German unification more positively than quality and left-wing newspapers. 
Melanie Leidecker-Sandmann, Jürgen Maier, Michaela Maier

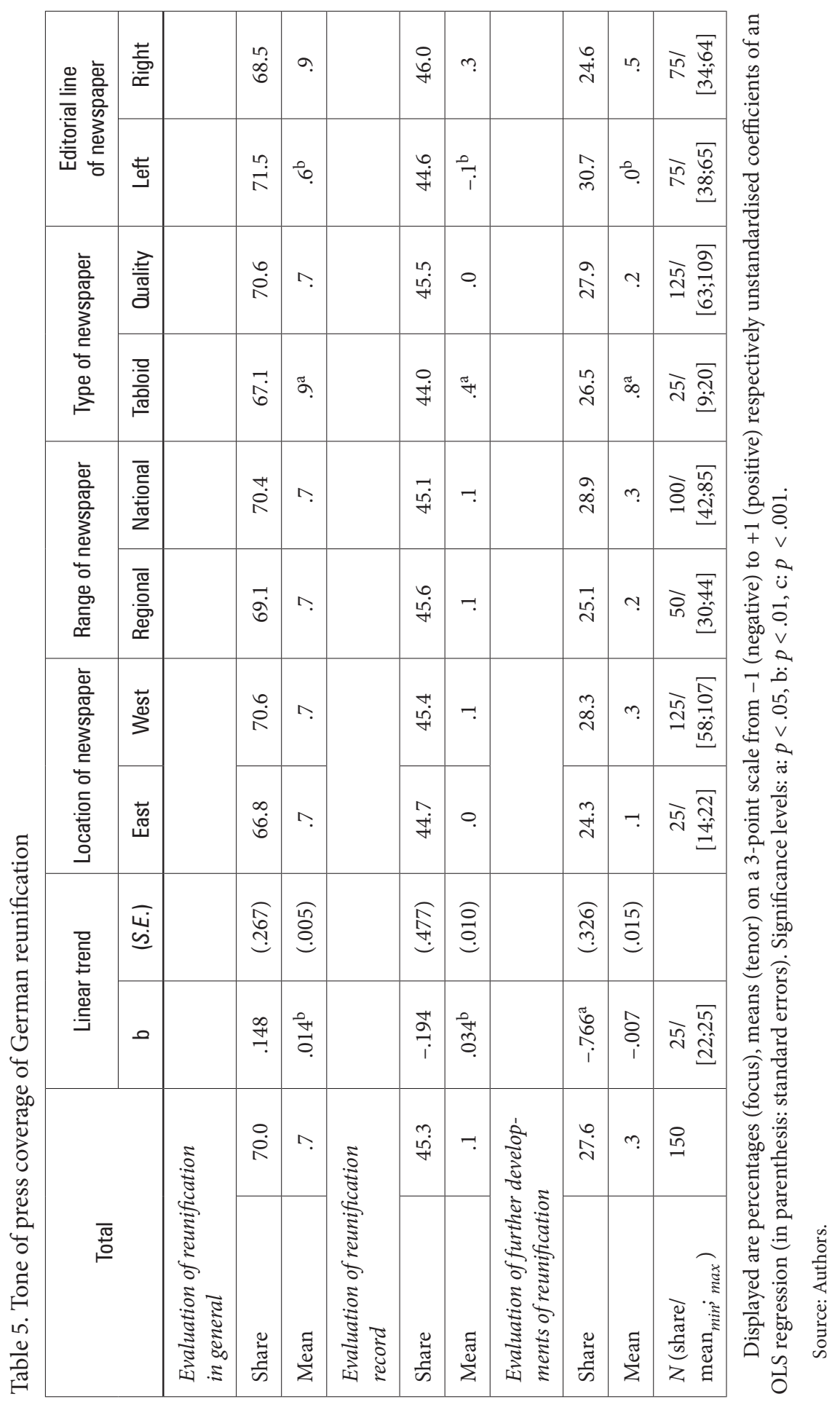


Press coverage of the German reunification issue

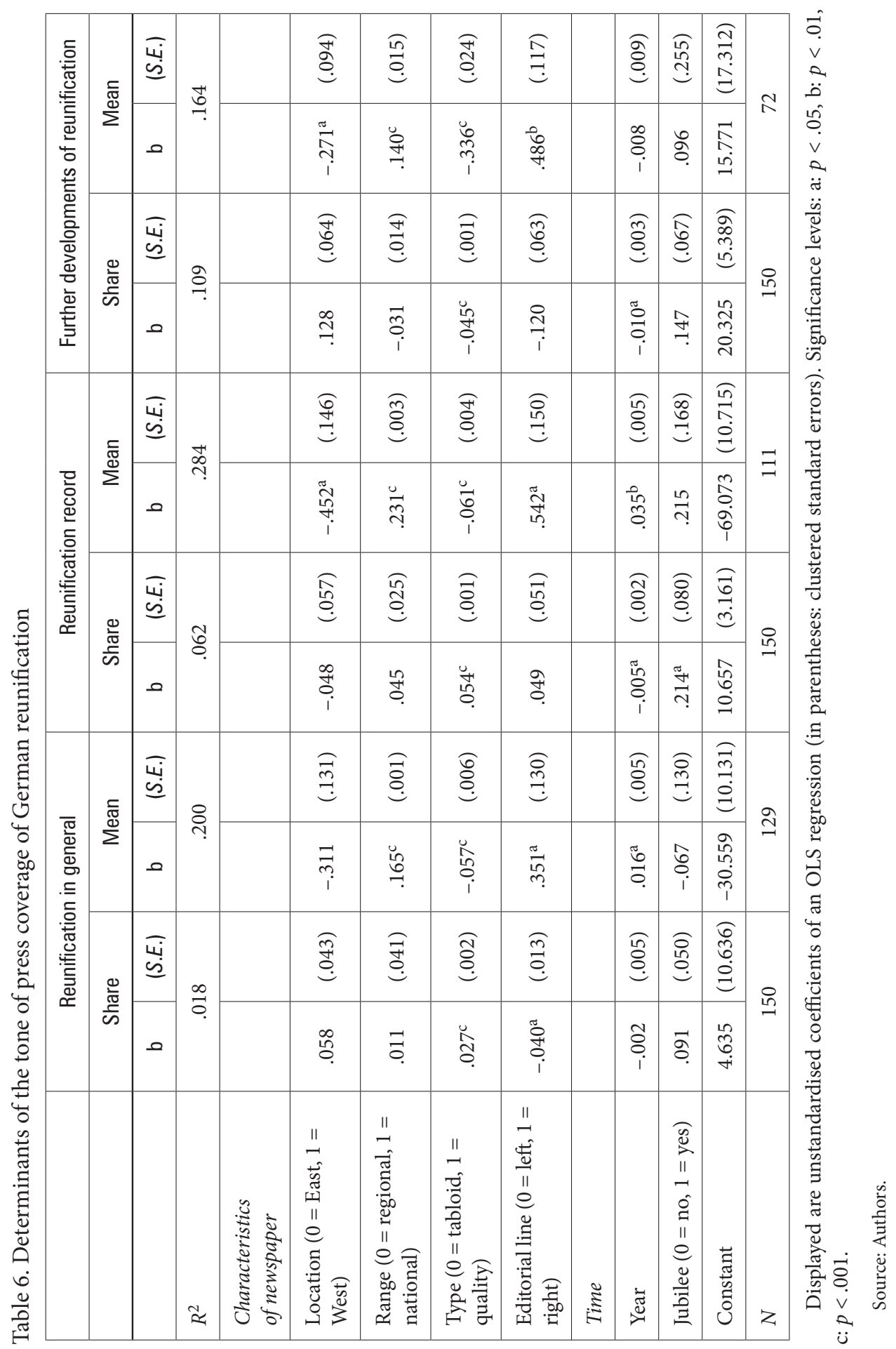


In analogy to the analyses of the placement of articles, the content of articles, and the share of articles including evaluations on German reunification, we estimate a multivariate model for the tone of the newspaper reports, too. It turns out that almost every characteristic of the newspaper has a significant influence on the tone of coverage (Table 6). In addition, the impact is very homogenous across the different indicators employed in this paper to capture journalistic evaluations of the German reunification issue: newspapers based in East Germany, national newspapers, tabloid newspapers, and conservative newspapers deliver more favourable judgments about the reunification, its record, and its future development than newspapers located in West Germany, regional newspapers, quality newspapers, and newspapers following a more liberal editorial line. Therefore, we can confirm H10 and H16, but have to reject H12.

In addition, time is an influential factor. Independent of the particular characteristics of a newspaper, evaluations on reunification (on average +.016 scale points) and the reunification record ( +.035 scale points) become more positive from year to year. Although there is no significant impact of time on future expectations about German reunification, our results support $\mathrm{H} 4$. In contrast, jubilee years have no significant impact on the ratings of German unification.

\section{SUMMARY AND CONCLUSION}

In this paper we have analysed the press coverage of the German reunification issue from a long-term perspective. We are interested in how often and how prominently the press covers this event, what the content of the coverage is, and how journalists evaluate selected aspects of the reunification process.

In addition, we are particularly interested in the question if newspapers cover German reunification differently. Although many citizens were personally affected by the consequences of the administrative and political implementation of German reunification, most people - especially those living in West Germany - received information about the complex and often turbulent developments only through the media. Hence, the media were (and probably still are) ${ }^{7}$ a crucial factor influencing the perceptions and attitudes towards German reunification and towards fellow citizens living in the other part of the country (Infratest dimap, 2016). If it turns out that the media differ in how they cover this issue, it is very likely that different audiences receive different impressions concerning this event. Taking into account that exposure to mass media can influence, for example, political knowledge, attitudes, and behaviour, these differences could have far-reaching consequences.

To answer these questions, we conducted a quantitative content analysis that goes beyond previous research. Firstly, our data set covers a much longer time period than other studies in this field. Secondly, due to the large number of variables coded we are able to make more detailed statements about the structure and the

${ }^{7}$ For instance, a recent survey indicates that significant parts of the East (West) German population have not visited West (East) Germany yet (Infratest dimap, 2016). 
development of media coverage than the available trend studies. Thirdly, our media set, which includes six German newspapers of different locations, ranges, types, and editorial lines provides more detailed insights into which factors are responsible for the way journalists cover and evaluate German reunification.

Our most important findings are:

1. Although there were high levels of media coverage in the beginning, German reunification is not a very important issue any more. Even on its special jubilees (i.e., the fifth, tenth, fifteenth, twentieth anniversary), the number of published articles is rather small.

2. Only a few articles are published on the front page. Regional frames are rare. Articles including information on the differences between both parts of the country outweigh reports on similarities. About one third of the coverage is focused on problems and conflicts. Differences and problems become less important over time. In this sense, the process of German reunification seems to move on, but it has not yet accomplished its goal.

3. Evaluations of reunification in general, the reunification record, or the future development of the reunification process are an important feature of press coverage. In general, positive judgments outweigh negative assessments. Over time, the share of articles including evaluations has declined, whereas the tone of coverage has become more favourable - another indicator of a successful integration of East and West Germany.

4. The placement of articles, its content, and particularly the evaluation of German reunification largely depend on the characteristics of a newspaper, that is, its location (East vs. West), range (regional vs. national), type (tabloid vs. quality), and editorial line (liberal vs. conservative). As a result, the impression a recipient gets about German reunification by being exposed to press coverage can be very different. In sum, the type of a newspaper most often has a significant impact on placement, content, and tone of coverage. In contrast to this, a significant influence of the location of a newspaper is relatively rare.

5. Although most of our hypotheses can be confirmed, an interesting finding is that all hypotheses associated with the impact of the type of newspaper have to be rejected (see Table 7). This result indicates that the coverage of the only tabloid newspaper in our sample, BILD, is exceptional. More than other newspapers, BILD is in favour of German reunification, highlights positive aspects, and downplays negative information.

The finding that the characteristics of newspapers have a strong influence on the coverage of the German reunification issue has two important implications. Firstly, it indicates that newspapers are (still) fighting for opinion leadership. Secondly, the presentation of different information on and interpretations of German reunification might have consequences for individual knowledge of and political attitudes towards this event as well as towards actors (e.g., former chancellor Helmut Kohl) and objects related to it (e.g., perceptions of the GDR). We strongly 
suggest matching content analysis and survey data to test this expectation in order to explain attitude differences towards German reunification (Gabriel et al., 2015).

Table 7. Overview of confirmed and rejected hypotheses

\begin{tabular}{|l|c|c|c|}
\hline $\begin{array}{c}\text { Factors potentially } \\
\text { affecting the coverage } \\
\text { of German reunification }\end{array}$ & Amount of coverage & $\begin{array}{c}\text { Placement and content } \\
\text { of coverage }\end{array}$ & Tone of coverage \\
\hline Time & H1, H2 & H3 & H4 \\
\hline Location of newspaper & H5, H6 & H10 \\
\hline Range of newspaper & H7, H8, H9 & H12 \\
\hline Type of newspaper & & H11 & H16 \\
\hline $\begin{array}{l}\text { Editorial line } \\
\text { of newspaper }\end{array}$ & H13, H14, H15 & \\
\hline
\end{tabular}

Bold font: confirmed hypotheses; normal type: rejected hypotheses.

Source: Authors.

Although our study provides detailed information about the structure and the development of media coverage on German reunification and therefore makes a significant contribution to the research in this field, it also has its limitations. Most importantly, our media set is quite limited. Our results are only based on the coverage of six newspapers. Among these, there is only one East German newspaper, one tabloid and two regional newspapers (against three national quality newspapers). Of course, the press scene in Germany is much more diverse - and other important media sources - TV, radio, internet - have been ignored in this study. With the wisdom of hindsight, we think especially an analysis of several (regional) East German newspapers would have been analytically interesting. Moreover, future studies could also include (or focus on) elements of qualitative analysis, to be able to describe a more detailed picture of press coverage of the German reunification issue and to get a better sense of the topics and arguments behind the quantitative data. In the context of our long-term analysis, we had to do without such qualitative analyses, as it would have gone beyond the scope of our study. Furthermore, we only analysed the coverage of German reunification on its anniversaries. Although previous research has indicated that most of the coverage happens around this day, we have no information about the coverage during the rest of the year. These questions might be investigated in future research.

\section{FUNDING}

The authors received financial support for their research from the Bundesministerium für Wirtschaft und Energie (Federal Ministry of Economic Affairs and Energy). 


\section{REFERENCES}

Ahbe, T. (2009). Die Ost-Diskurse als Strukturen der Nobilitierung und Marginalisierung von Wissen. Eine Diskursanalyse zur Konstruktion der Ostdeutschen in den westdeutschen Medien [Eastern discourses as structures of the nobilitation and marginalisation of knowledge]. In: T. Ahbe, R. Gries \& W. Schmale (eds.), Die Ostdeutschen in den Medien. Das Bild von den Anderen nach 1990 [East Germans in media]. Leipzig: Leipziger Universitäts-Verlag, pp. 59-112.

Berliner Verlag (2014). Mediadaten 2014 [Media data 2014]. Retrieved December 15, 2014 from http://www.die-zeitungen.de/fileadmin/files/documents/Tarife_PDF_2014/Berliner-Zeitungund-Berliner-Kurier-2014.pdf.

Berliner Zeitung (2014). Berliner Zeitung hat die meisten Leser [Berliner Zeitung has the most readers]. Retrieved December 15, 2014 from http://www.berliner-zeitung.de/medien/media-analyse2013-berliner-zeitung-hat-die-meisten-leser,10809188, 23888730.html.

Brichta, M. (2006). Boulevardberichterstattung [Tabloid coverage]. In: Hans-Bredow-Institut (ed.), Medien von A bis Z [Media from A to Z]. Wiesbaden: VS Verlag, pp. 59-62.

Engesser, S., Esser, F., Reinemann, C., Scherr, S., Matthes, J., \& Wonneberger, A. (2014). Negativität in der Politikberichterstattung. Deutschland, Österreich und die Schweiz im Vergleich [Negativity in political coverage]. Medien \& Kommunikationswissenschaft, 62, pp. 588-605.

Früh, W., Hasebrink, U., Krotz, F., Kuhlmann, C., \& Stiehler, H. (1999). Ostdeutschland im Fernsehen [East Germany on TV]. München: KoPäd.

Früh, W., Stiehler, H. J., Früh, H., \& Böttcher, C. (2011). Mediale Vereinigungs-Bilanzen. Ost- und Westdeutschland im Fernsehen: Event- und Alltagsberichterstattung [Medial reunification balances. East and West Germany on television]. Berlin: Vistas-Verlag.

Gabriel, O. W., Holtmann, E., Jaeck, T., Leidecker-Sandmann, M., Maier, J., \& Maier, M. (2015). Deutschland 25. Gesellschaftliche Trends und politische Einstellungen [Germany 25. Social trends and political attitudes]. Bonn: Bundeszentrale für politische Bildung.

Infratest dimap (2016). Ost- und Westdeutsche sind sich näher gekommen [East and West Germans converge]. Retrieved November 12, 2016 from www.infratest-dimap.de/umfragen-analysen/bun desweit/umfragen/aktuell/ost-und-westdeutsche-sind-sich-naeher-gekommen/.

Kepplinger, H. M., \& Weißbecker, H. (1991). Negativität als Nachrichtenideologie [Negativity as newsideology]. Publizistik, 36, pp. 340-341.

Kollmorgen, R., \& Hans, T. (2011). Der verlorene Osten. Massenmediale Diskurse über Ostdeutschland und die Deutsche Einheit [The lost east. Mass medial discourses on East Germany and the German reunification]. In: R. Kollmorgen, F. K. Koch \& H. Dienel (eds.), Diskurse der Deutschen Einheit. Kritik und Alternativen [Discourses of the German reunification]. Wiesbaden: VS Verlag, pp. 107-165.

Kolmer, C. (2009). Nachrichten aus einer Krisenregion. Das Bild Ostdeutschlands und der DDR in den Medien 1994-2007 [News from a crisis region. The image of East Germany and the DDR in media 1994-2007]. In: T. Ahbe, R. Gries \& W. Schmale (eds.), Die Ostdeutschen in den Medien. Das Bild von den Anderen nach 1990 [East Germans in media. The image of "the others" after 1990]. Leipzig: Leipziger Universitäts-Verlag, pp. 181-214.

Korngiebel, W., \& Link, J. (1992). Von einstürzenden Mauern, europäischen Zügen und deutschen Autos. Die Wiedervereinigung in Bildern und Sprachbildern der Medien [The reunification in pictures and verbal images of media]. In: R. Bohn, K. Hickethier \& E. Müller (eds.), Mauer-Show. Das Ende der DDR, die Deutsche Einheit und die Medien [The end of the DDR, German reunification and the media]. Berlin: Edition Sigma, pp. 31-54.

Leidecker, M. (2015). Das ist die Topgeschichte des Tages! Der Aufmacher-Artikel deutscher Tageszeitungen im Vergleich [Lead stories in German daily newspapers - a comparison]. Köln, Weimar \& Wien: Böhlau. 
Löser, M. (2013). Wende und Wiedervereinigung in der Presse. Untersuchungen zur Berichterstattung in regionalen und überregionalen Tageszeitungen anlässlich des zwanzigsten Jahrestages der friedlichen Revolution von 1989 [The German turnaround and reunification in the press]. Berlin: Verlag Dr. Köster.

Maurer, M. (2010). Agenda Setting. Baden-Baden: Nomos.

Maurer, M., \& Reinemann, C. (2006). Medieninhalte. Eine Einführung [Media content. An introduction]. Wiesbaden: VS Verlag.

Media Tenor (2016a). ARD, RTL + ZDF tragen wenig zum Verständnis der Einheit bei. Berichterstattung über die Deutsche Einheit und die DDR in den Hauptnachrichtensendungen von ARD, RTL und ZDF Jan 1996 - Sep 2010 [ARD, RTL and ZDF contribute little to the understanding of reunification]. Retrieved from Media Tenor newsletter: 2016.

Media Tenor (2016b). 25 Jahre Deutsche Einheit: Übergang zur Tagesordnung und viel Negativität [25 years of German reunification]. Retrieved February 4, 2016 from http://de.mediatenor. $\mathrm{com} / \mathrm{de} / \mathrm{bibliothek} /$ newsletter/481/25-jahre-deutsche-einheit-uebergang-zur-tagesordnungund-viel-negativitaet.

Media Tenor (2016c). Ernüchterung zum Tag der Einheit 2016 [Disillusionment on the day of reunification 2016]. Retrieved November 15, 2016 from http://ch.mediatenor.com/de/bibliothek/ newsletter/1063/ernuechterung-zum-tag-der-einheit-2016.

Noelle-Neumann, E. (1983). Neue Forschungen im Zusammenhang mit der Schweigespiralen-Theorie [New research in connection with the spiral of silence-theory]. In: U. Saxer (ed.), Politik und Kommunikation. Neue Forschungsansätze [Politics and communication]. München: Ölschläger, pp. 133-153.

Reumann, K. (2002). Journalistische Darstellungsformen [Journalistic formats]. In: E. Noelle-Neumann, W. Schulz \& J. Wilke (eds.), Fischer Lexikon Publizistik Massenkommunikation [Fischer encyclopedia of communication science and mass communication]. Frankfurt am Main: Fischer, pp. 129-167.

Rother, R. (1992). Jahrestag - Fernsehtag. Der 9.11.89 im TV, ein Jahr danach [November 9th, 1989 on TV, one year later]. In: R. Bohn, K. Hickethier \& E. Müller (eds.), Mauer-Show. Das Ende der DDR, die Deutsche Einheit und die Medien [The end of the DDR, German reunification and the media]. Berlin: Edition Sigma, pp. 157-174.

Scheufele, D. A., \& Tewskbury, D. (2007). Framing, agenda-setting, and priming: The evolution of three media effect models. Journal of Communication, 57(1), pp. 9-20.

Schulz, W. (1976). Die Konstruktion von Realität in den Nachrichtenmedien. Analyse der aktuellen Berichterstattung [The construction of reality in news media]. Freiburg, München: Alber.

Schulz, W. (2001). Politische Mobilisierung durch Mediennutzung? Beziehungen zwischen Kommunikationsverhalten, politischer Kompetenz und Partizipationsbereitschaft [Political mobilisation through media use]. In: A. Koch, M. Wasmer \& P. Schmidt (eds.), Politische Partizipation in der Bundesrepublik Deutschland: empirische Befunde und theoretische Erklärungen [Political participation in the Federal Republic of Germany: Empirical results and theoretical explanations]. Opladen: Leske + Budrich, pp. 177-180.

Schulz, W. (2011). Politische Kommunikation. Theoretische Ansätze und Ergebnisse empirischer Forschung [Political communication. Theoretical approaches and results of empirical research]. Wiesbaden: Springer VS. 